\title{
Synthesis of Phenanthridine by Palladium Catalyzed Suzuki Coupling and Condensation Reaction
}

\section{Jayanta K Ray* and Suvendu Dhara}

Department of Chemistry, Indian Institute of Technology, Kharagpur 721302, India

\section{jkray@chem.iitkgp.ac.in}

\section{Introduction}

Transition metal catalyzed cross-coupling reactions such as Suzuki-Miyaura ${ }^{1}$, Heck ${ }^{2-10}$, Stille $^{11}$, Hiyama, ${ }^{12}$ Negishi $^{13}$, and Sonogashira reactions are likely to be the most power tool for the formation of $\mathrm{C}-\mathrm{C}$ bonds for the past four decades. All these reactions have shown their widespread applicability ranging from academic area to research. Some of the reactions have also been applied in pharmaceuticals, agrochemicals, and fine material industries. The Suzuki-Miayura cross coupling was remained the most attractive alternative for C-C bonds formation since its discovery in 1979. The wide range of applicability of this reaction is largely attributed to mild reaction conditions, broad range of functional group tolerance, easy access to organo-boron reagents, and their stability under air and moisture. Furthermore, boron compounds show low toxicity and easy to separate boron from the reaction mixtures.

Phenanthridine (3.1) is a nitrogen heterocycle that is the basis of DNA-binding fluorescent dyes through intercalation. Ethidium bromide and propidium iodide are the examples of such intercalating dyes. Phenanthridine is an isomeric compound of acridine (3.2) (Fig. 3.1).

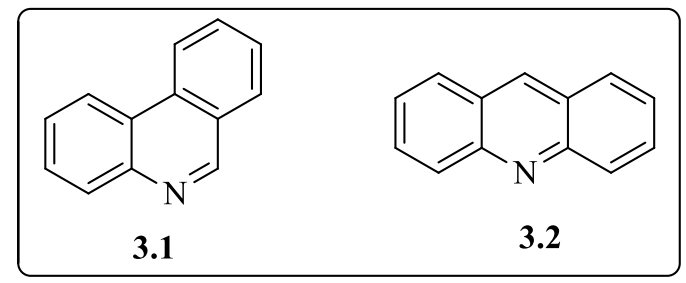

Fig. 3.1: Phenanthridine and acridine

Phenanthridine was first discovered by Ame Pictet and H. J. Ankersmit in 1891 by pyrolysis of the condensed product of benzaldehyde and aniline. Earlier, phenanathridine and related 
compounds were prepared using mainly Pictect-Hurbert and modified Morgan-Walls type of condensation reactions.

\subsubsection{Bioactivity and natural occurrences}

Phenanthridines and Benzo[c]phenanthridines are prevalent in a large number of natural and unnatural bioactive molecules exhibiting important pharmacological activities and applications, such as antibacterial, antiprotozoal, and anticancer agents. A well known member of this class of compound is ethidium (3.3), a common DNA intercalator and stain. Representative alkaloids of this kind with promising pharmacological potential are nitidine (3.4), chelerythrine (3.5), sanguinarine (3.6) (Fig. 3.2).

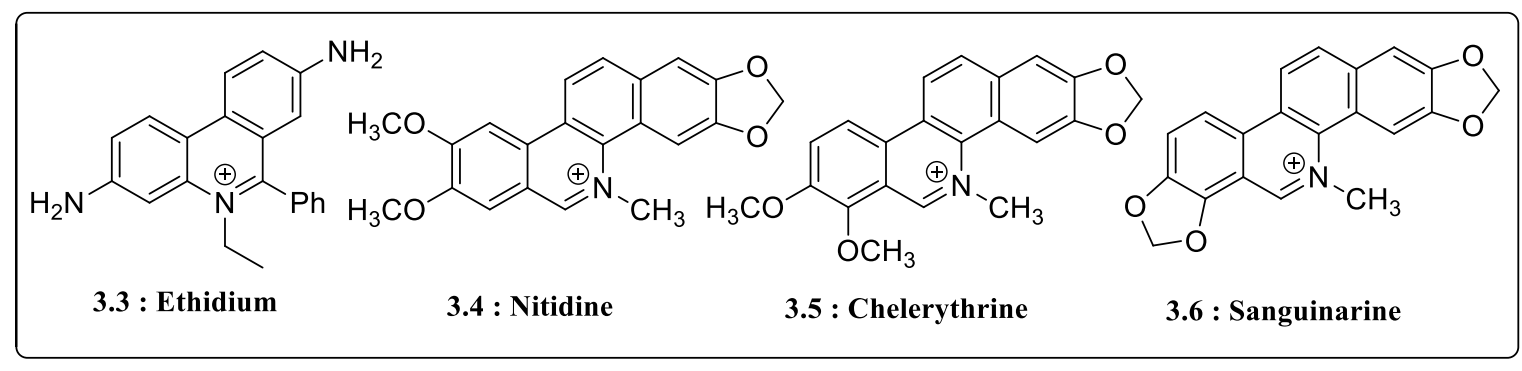

Fig. 3.2: Some phenanathridiene and benzo[c]phenanthridine alkaloids.

Because of great importance of these compounds in biology and medicine, shorter and high yielding synthetic methodologies are of great interest in synthetic organic chemistry as isolation from natural sources described is less than $1 \%$.

In literature, various reports are there to construct these heterocycles. Among them, the Bischler-Napieralski cyclisation has been extensively used to synthesise phenanthridine derivatives. Wang et al. reported a cascade approach to 6-arylphenanthridine $\mathbf{3 . 1 0}$ from aromatic aldehyde 3.8, aniline 3.9 and benzenediazonium-2-carboxylate 3.7 (Scheme 3.1). The in situ generated benzyne from benzenediazonium-2-carboxylate 3.7 underwent a [4+2] cycloaddition reaction with the imine formed from aromatic amine and aldehyde to give dihydrophenanthridine. Finally, dehydrogenation in the reaction medium gave the 6-arylated phenanthridine 3.10 in quantitative yields. 


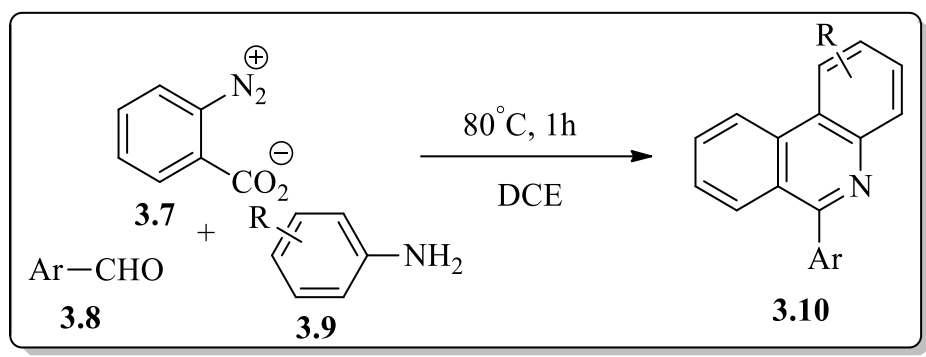

Scheme 3.1: Cascade approach to phenanthridine

Deiters et al. described a cyclotrimerization approach to build the phenanthridine moiety. Different transition metal complexes have been evaluated to catalyze the cyclotrimarization and the Ru-catalyst results the best. The Ru-catalyzed microwave assisted $[2+2+2]$ cyclotrimerisation of diyne $\mathbf{3 . 1 1}$ afforded to dihydrophenanthridine 3.12. Then CAN mediated deprotective aromatization ultimately gave the substituted phenanthridine $\mathbf{3 . 1 3}$ (Scheme 3.2).

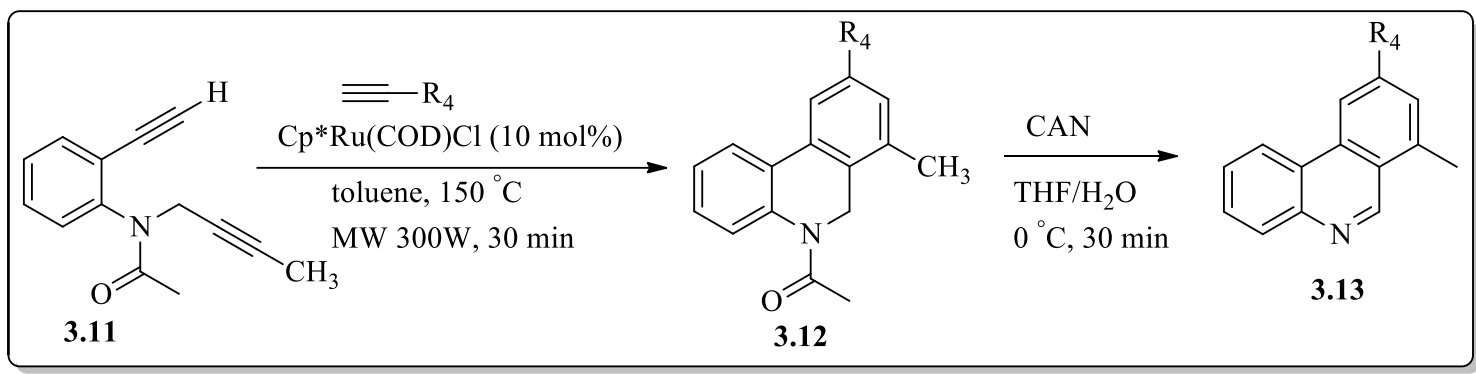

Scheme 3.2: Cyclotrimerisation towards phenanthridine

In other way Yanada et al. constructed analogous benzo[c]phenanthridine via Lewis acid catalyzed tandem cyclization. The Lewis acid In(OTf $)_{3}$ cyclizes ortho-alkynylbenzaldehydes 3.14 and ortho-alkynylanilines $\mathbf{3 . 1 5}$ to form the benzo[c]phenanthridine $\mathbf{3 . 1 6}$ in very good yields (Scheme 3.3). A series of other Lewis catalysts have been screened to effect the cyclization and $\operatorname{In}(\mathrm{OTf})_{3}$ was proved to be the best. The reaction goes via 6-endo-dig nucleophilic addition of carbonyl oxygen on the $\operatorname{In}(\mathrm{OTf})_{3}$ co-ordinated electrophilic $o$-alkynyl moiety to give the pyrilium cation intermediate. The intermediate pyrilium cation undergoes a Diels-Alder type cyclization with the $o$-alkynylaniline and followed by condensation to give the final product $\mathbf{3 . 1 6}$. 


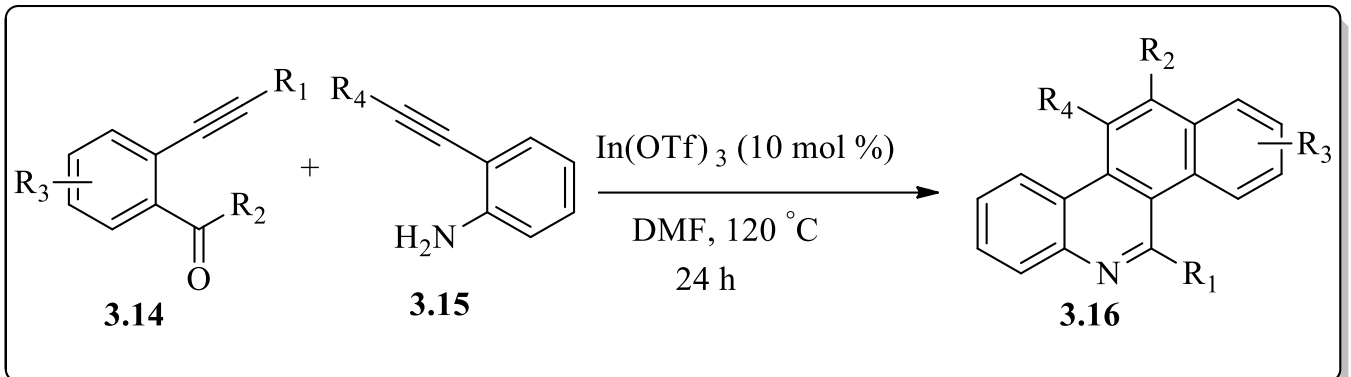

Scheme 3.3: Lewis acid catalysed Tandem cyclization

Annulation of acyloximes with aryne or alkyne has been adopted by Zhu and co-workers (Scheme 3.4). Among a series of palladium catalysts allyl-palladium complex (APC) along with a bulky phosphine ligand were the most promising catalytic system. The oxidative palladium insertion into the $\mathrm{N}-\mathrm{O}$ bond of acyloxime 3.17 and cis-aminopalladation to the benzyne formed from the compound 3.18, followed by intramolecular $\mathrm{C}-\mathrm{H}$ activation afforded the 6-phenylphenanthridine 3.19.

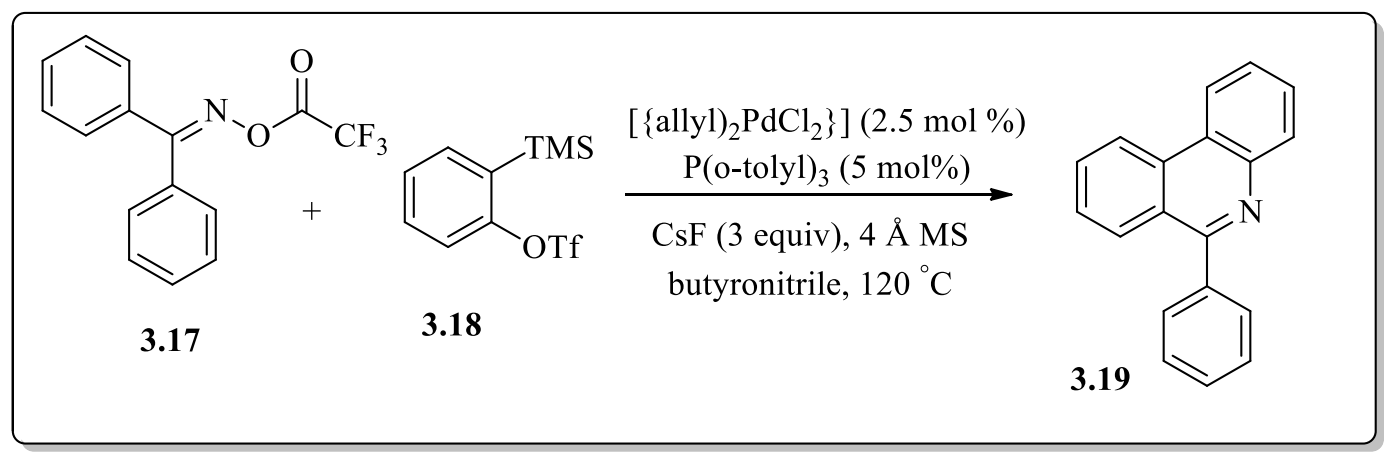

Scheme 3.4: APC -catalyzed synthesis of phenanthridine

Palladium catalyzed synthesis of phenanthridine has been accomplished by Pritchard and coworkers from imidoyl selenides. This was the first report of palladium insertion into the C-Se bond. The palladium insertion into the imidoyl selenides 3.20 followed by intramolecular cyclization and subsequent aromatization via the elimination of $\mathrm{HSePh}$ lead to the formation of substituted phenanthridines 3.21 (Scheme 3.5).

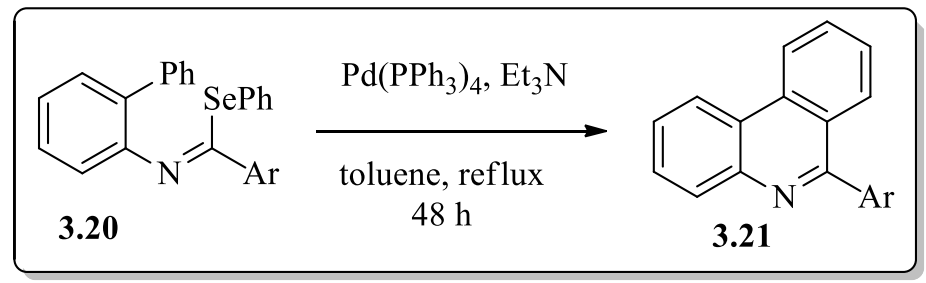


Scheme 3.5: Pd-catalysed synthesis of phenanathridine

A cascade reaction of $N$-acetylated biaryl $\mathbf{3 . 2 2}$ for the construction of phenanthridine ring has been described by Yao et al. The amide of biphenyl-2-amine undergoes a cascade annulations reaction initiated by Hendrickson reagents and subsequent Friedel-Crafts reaction to afford the 6-methyl phenanthridine $\mathbf{3 . 2 3}$ under mild reaction conditions (Scheme 3.6).

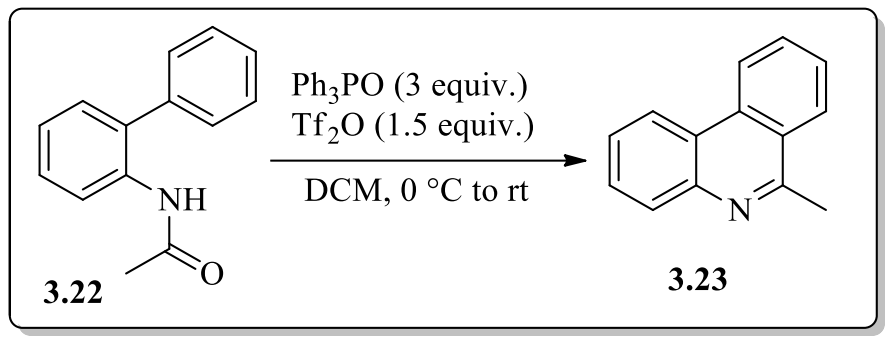

Scheme 3.6: Cascade synthesis of phenanthridine

Alternatively, Lautens group have synthesized phenanthridine by domino arylation, $\mathrm{N}$ arylation protocol under $\mathrm{Pd}$-catalysis. The $\mathrm{Pd}(\mathrm{OAc})_{2}$ catalyzed domino $\mathrm{N}$-arylation of the silylimine 3.25 with aryl iodide $\mathbf{3 . 2 4}$ and followed by intramolecular C-H-activation produced the substituted phenanthridine $\mathbf{3 . 2 6}$ (Scheme 3.7).

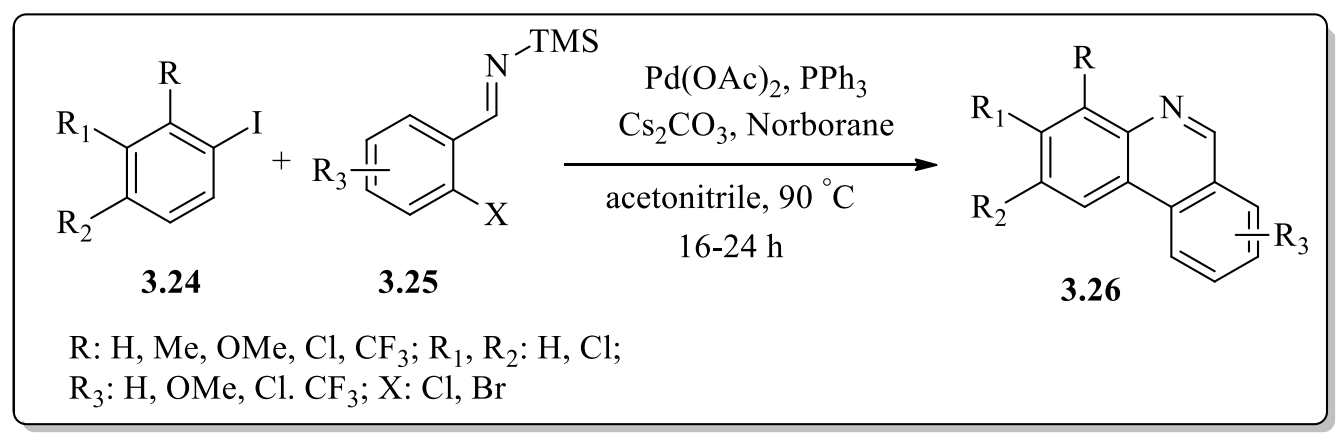

Scheme 3.7: Convenient synthesis of phenanthridine

A very simple method of non-nucleophilic base ${ }^{\mathrm{t}} \mathrm{BuOK}$ mediate condensation between 2methylbenzonitrile 3.28 and an arylaldehyde 3.27 has been demonstrated by Clement et al. Subsequently, resulting 6-amino-11,12-dihydrobenzo[c]phenanthridine $\mathbf{3 . 2 9}$ was converted to 11-substituted 6-aminobenzo[c]phenanthridine 3.30 via DDQ oxidation (Scheme 3.8). 


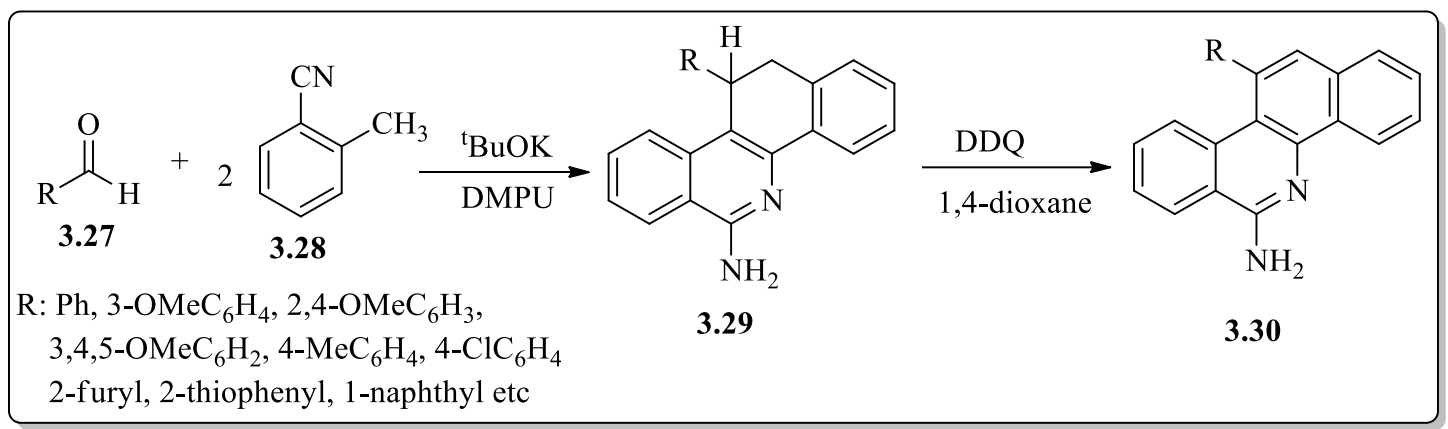

Scheme 3.8: Synthesis of 6-aminobenczo[c]phenanthridine

An efficient method for the formation of $[c]$ annulated isoquinoline has been developed by Pandey et al. via Pd-mediated sequential reactions. The Suzuki cross coupling between $\alpha-$ iodoenone 3.32 and protected aminoboronic acid 3.31, and subsequent condensation results the $[c]$ annulated isoquinoline derivatives 3.33 (Scheme 3.9).

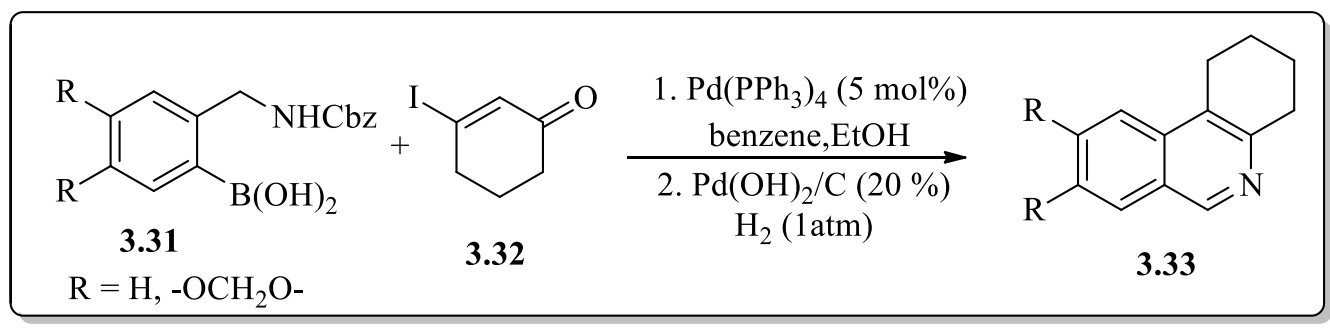

Scheme 3.9: Sequential reaction towards the formation of $[c]$ annulated isoquinoline

Dominguez et al. applied a two-step synthetic protocol towards the efficient synthesis of novel dibenzo $[a, c]$ phenanathridine. Highly substituted novel dibenzo $[a, c]$ phenanthridines 3.35 have been prepared from aryl ketone $\mathbf{3 . 3 4}$ via sequential reactions of Ritter-type heterocyclization and the classical two-step reductive amination/Bischler-Napieralski cyclization (Scheme 3.10).

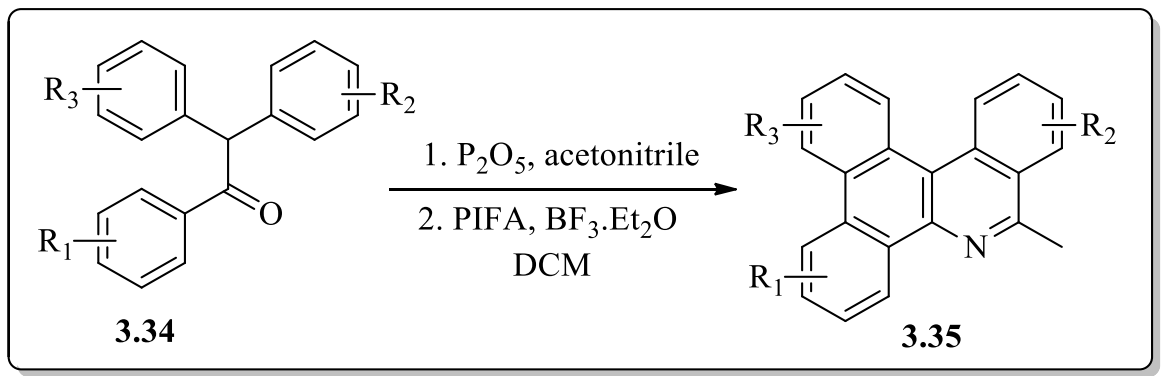

Scheme 3.10: Synthesis of dibenzo[a,c]phenanthridine 
In our continuous effort in finding the shorter and economic synthetic methods via palladium catalysis, we have achieved a synthesis of phenanthridines and its analogs in this chapter. Our aim was to find out one step method for the synthesis of phenanthridine. We envisioned that Suzuki coupling between $\mathbf{3 . 3 6}$ and $\mathbf{3 . 3 7}$ would be very effective for the construction of phenanathridine 3.38 in one-pot (Scheme 3.11).

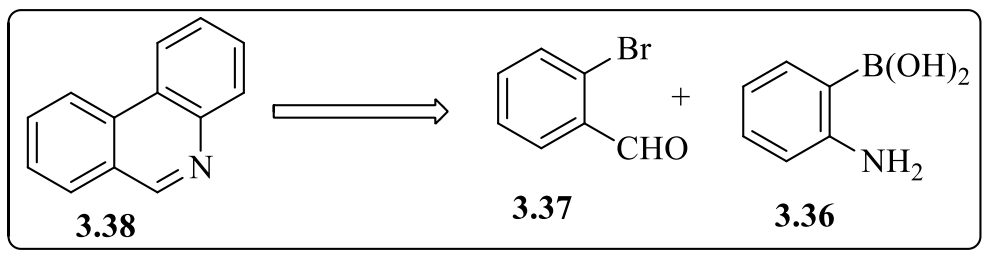

Scheme 3.11: Retrosynthesis of phenanthridine

\section{Results and Discussions}

We report a one-pot strategy to achieve phenanthridine $\mathbf{3 . 3 8}$ and analogous derivatives $\mathbf{3 . 4 1}$ or 3.42 via Suzuki coupling of suitably substituted aromatic ortho-bromoaldehyde 3.39 or 3.40 and ortho-aminobenzenboronic acid 3.36 in quantitative to good yields (Scheme 3.12).

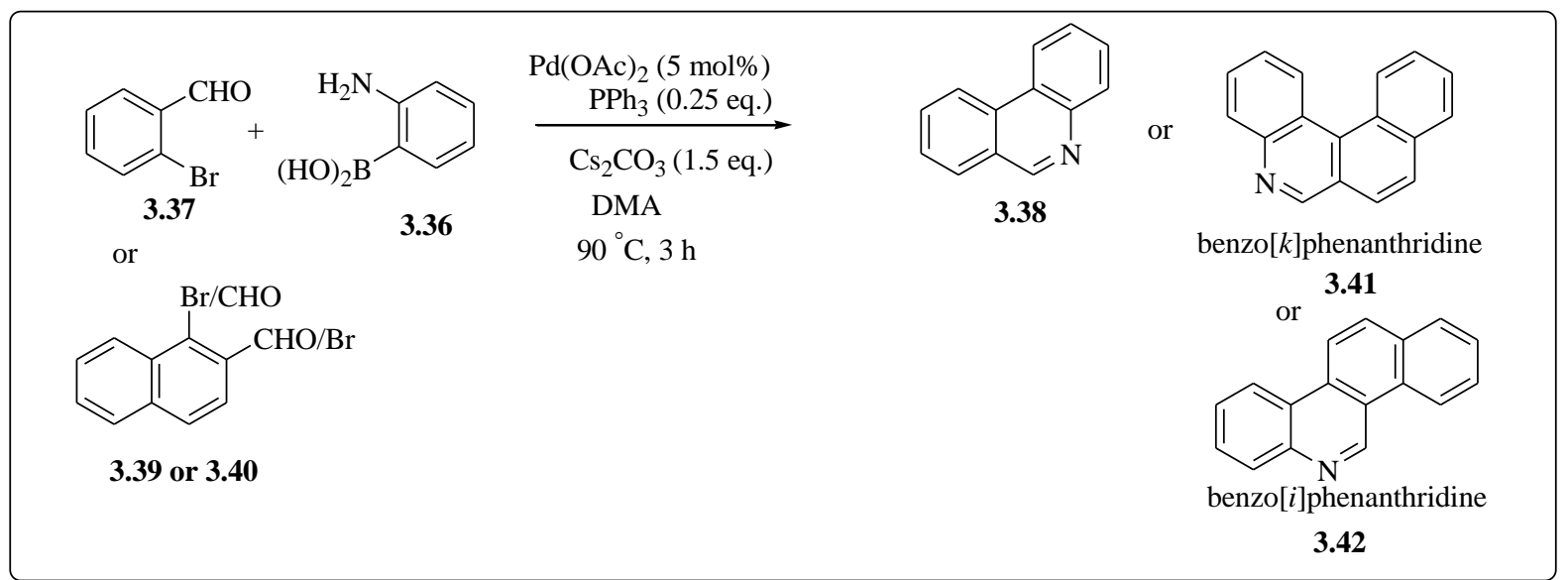

Scheme 3.12: Synthesis of phenanthridine and its analogues

For the synthesis of phenanthridine analogs the starting aromatic $o$-bromoaldehydes $\mathbf{3 . 4 5}$ were synthesized by Vilsmeier-Haack reaction upon corresponding ketones $\mathbf{3 . 4 3}$ and followed by DDQ aromatization of $o$-bromoaldehyde 3.44 (Scheme 3.13). 


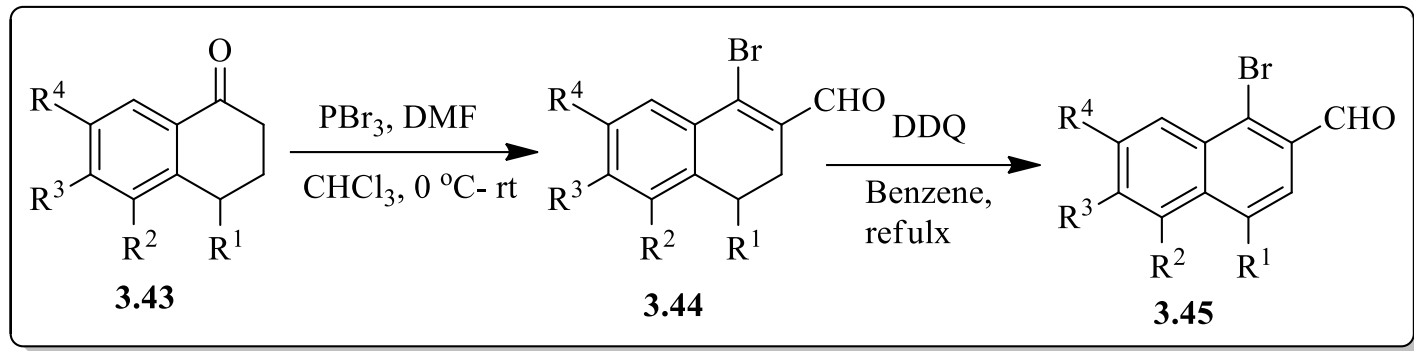

Scheme 3.13: Synthesis of the aromatic $o$-bromoaldehyde

We have attempted the coupling step with 2-bromobenzaldehyde $\mathbf{3 . 3 7}$ and 2aminobenzeneboronic acid 3.36. A variety of the palladium catalysts were tried in combination with ligand and different organic or inorganic bases as the catalytic system. The palladium (0) catalysts $\mathrm{Pd}\left(\mathrm{PPh}_{3}\right)_{4}$ and $\mathrm{Pd}_{2}(\mathrm{dba})_{3}$ gave phenanathridines 41 to $60 \%$. Among the palladium(II) catalysts the $\mathrm{Pd}(\mathrm{OAc})_{2}$ was the best catalyst with $95 \%$ formation of phenanthridine 3.38. The inorganic base $\mathrm{Cs}_{2} \mathrm{CO}_{3}$ was proved to be superior to its other inorganic and organic analogues. When the reaction was carried out at $80{ }^{\circ} \mathrm{C}$ the reaction gave only $50 \%$ of phenanathridine in the presence of $\mathrm{Pd}\left(\mathrm{PPh}_{3}\right)_{2} \mathrm{Cl}_{2}, \mathrm{Et}_{3} \mathrm{~N}$, and in $\mathrm{DMF}$ solvent. Increasing the reaction temperature to $90{ }^{\circ} \mathrm{C}$ afforded $82 \%$ of phenanthridine in the presence of $\mathrm{Pd}(\mathrm{OAc})_{2}, \mathrm{PPh}_{3}$ and $\mathrm{K}_{2} \mathrm{CO}_{3}$ catalytic system in DMF in $5 \mathrm{~h}$. Changing the base to $\mathrm{Cs}_{2} \mathrm{CO}_{3}$ and solvent to DMA shorten the reaction time from 5 to $3 \mathrm{~h}$ with $95 \%$ of yields. Further increase of reaction temperature and changing the solvent to DMSO has no effect on the reaction. So, the set of optimal reaction conditions were finalized to be $\mathrm{Pd}(\mathrm{OAc})_{2}(5 \mathrm{~mol}$ $\%), \mathrm{PPh}_{3}$ (0.25 equiv.), $\mathrm{Cs}_{2} \mathrm{CO}_{3}$ (1.5 equiv.), in DMA $(3 \mathrm{~mL})$, at $90{ }^{\circ} \mathrm{C}$, for $3 \mathrm{~h}$ (Table 3.1 , entry 10).

Table 3.1: Catalyst Screening ${ }^{a}$

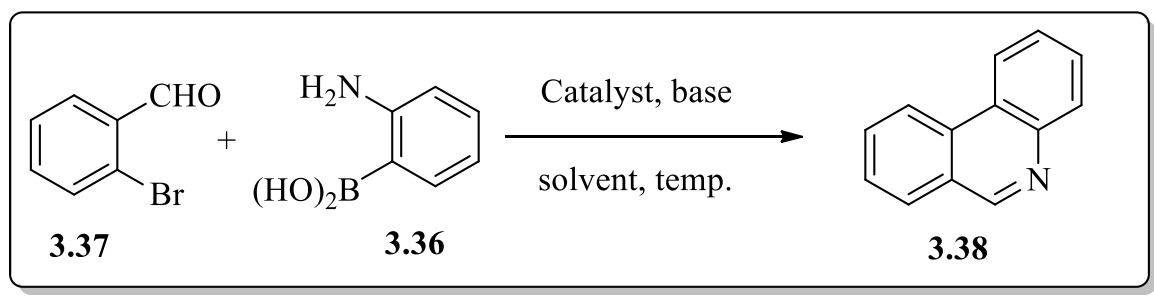

\begin{tabular}{|c|c|c|c|c|c|c|c|}
\hline Entry & Catalyst & Ligand & Base & Solvent & $\mathrm{T}(\mathrm{h})$ & Temp $\left({ }^{\circ} \mathrm{C}\right)$ & Yields $(\%)^{\mathrm{b}}$ \\
\hline 1 & $\mathrm{Pd}\left(\mathrm{PPh}_{3}\right)_{2} \mathrm{Cl}_{2}$ & - & $\mathrm{Et}_{3} \mathrm{~N}$ & $\mathrm{DMF}$ & 5 & 80 & 50 \\
\hline 2 & $\mathrm{PdCl}_{2}$ & $\mathrm{PPh}_{3}$ & $\mathrm{Et}{ }_{3} \mathrm{~N}$ & $\mathrm{DMF}$ & 5 & 80 & 80 \\
\hline 3 & $\mathrm{Pd}_{2}(\mathrm{dba})_{3}$ & - & $\mathrm{Et}_{3} \mathrm{~N}$ & $\mathrm{DMF}$ & 5 & 80 & 41 \\
\hline
\end{tabular}




\begin{tabular}{|c|c|c|c|c|c|c|c|}
\hline 4 & $\mathrm{Pd}\left(\mathrm{CH}_{3} \mathrm{CN}\right)_{2} \mathrm{Cl}_{2}$ & $\mathrm{PPh}_{3}$ & $\mathrm{Et}_{3} \mathrm{~N}$ & $\mathrm{DMF}$ & 5 & 80 & 63 \\
\hline 5 & $\mathrm{Pd}\left(\mathrm{PPh}_{3}\right)_{4}$ & - & $\mathrm{Et}_{3} \mathrm{~N}$ & $\mathrm{DMF}$ & 5 & 80 & 60 \\
\hline 6 & $\mathrm{Pd}(\mathrm{OAc})_{2}$ & $\mathrm{PPh}_{3}$ & $\mathrm{Et}_{3} \mathrm{~N}$ & $\mathrm{DMF}$ & 5 & 80 & 72 \\
\hline 7 & $\mathrm{Pd}(\mathrm{OAc})_{2}$ & $\mathrm{PPh}_{3}$ & $\mathrm{~K}_{2} \mathrm{CO}_{3}$ & $\mathrm{DMF}$ & 5 & 90 & 82 \\
\hline 8 & $\mathrm{Pd}(\mathrm{OAc})_{2}$ & $\mathrm{PPh}_{3}$ & $\mathrm{Na}_{2} \mathrm{CO}_{3}$ & $\mathrm{DMF}$ & 5 & 90 & 74 \\
\hline 10 & $\mathrm{Pd}(\mathrm{OAc})_{2}$ & $\mathrm{PPh}_{3}$ & $\mathrm{Cs}_{2} \mathrm{CO}_{3}$ & DMF & 3 & 90 & 90 \\
\hline 11 & $\mathrm{Pd}(\mathrm{OAc})_{2}$ & $\mathrm{PPh}_{3}$ & $\mathrm{Cs}_{2} \mathrm{CO}_{3}$ & DMA & 3 & 90 & 95 \\
\hline 12 & $\mathrm{Pd}(\mathrm{OAc})_{2}$ & $\mathrm{PPh}_{3}$ & $\mathrm{Cs}_{2} \mathrm{CO}_{3}$ & DMSO & 3 & 90 & 51 \\
\hline 13 & $\mathrm{Pd}(\mathrm{OAc})_{2}$ & - & $\mathrm{Cs}_{2} \mathrm{CO}_{3}$ & DMA & 3 & 90 & 40 \\
\hline
\end{tabular}

a) $1 \mathrm{mmol}$ of 3.37, $1.2 \mathrm{mmol}$ of 3.36, $\mathrm{Pd}(\mathrm{OAc})_{2}$ ( $\left.5 \mathrm{~mol} \%\right), \mathrm{PPh}_{3}\left(0.25\right.$ equiv.), $\mathrm{Cs}_{2} \mathrm{CO}_{3}$ (1.5 equiv.), DMA ( $3 \mathrm{~mL}), 90{ }^{\circ} \mathrm{C}, 3-5 \mathrm{~h}$.

b) Isolated yields.

Once we got the standard conditions for the cyclization procedure, we have generalized our methodology synthesizing various types of phenanthridine and analogous derivatives in excellent to good yields. The results are shown in the Table 3.2. Different substituted phenanthridines 3.38a-f were synthesized from the corresponding 2-bromobenzaldehydes 3.37a-f in good yields. The results in the Table 3.2 shows that this methodology is well tolerated both the electron-donation and electron with-drawing functionalities such as, nitro, methyl, methoxy group in the coupling partner 3.7.

Table 3.2: Synthesis of phenanthridine derivatives ${ }^{c}$

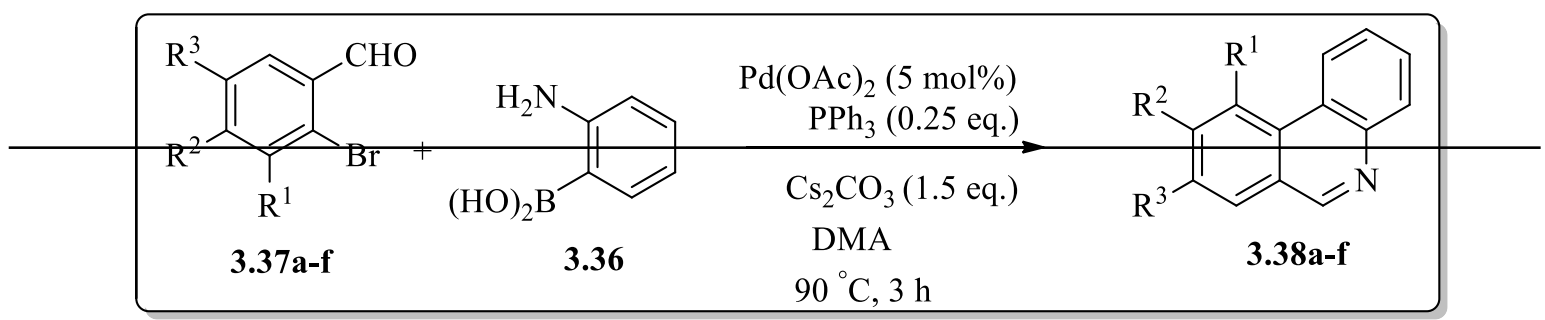

\begin{tabular}{|l|l|l|l|}
\hline Entry & Substrate & ${\text { Yields }(\%)^{\mathrm{d}}}^{\text {Products }}$ \\
\hline 1 & & \\
\hline
\end{tabular}




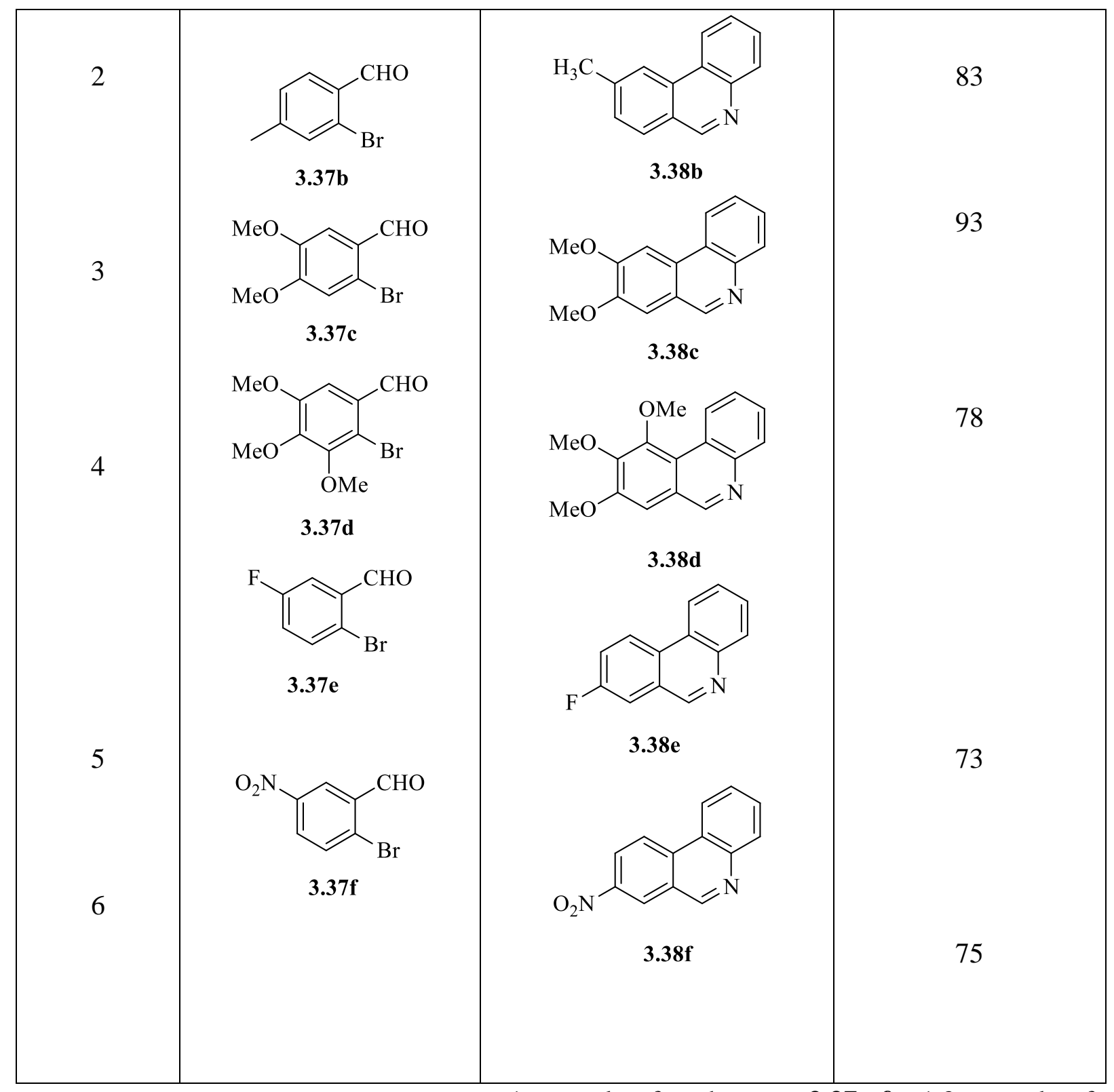

c) Reaction Conditions and Reagents: $1 \mathrm{mmol}$ of substrate $\mathbf{3 . 3 7 a - f}, 1.2 \mathrm{mmol}$ of aminobenzeneboronic acid 3.36, $\mathrm{Pd}(\mathrm{OAc})_{2}$ ( $\left.5 \mathrm{~mol} \%\right), \mathrm{PPh}_{3}$ (0.25 equiv.), $\mathrm{Cs}_{2} \mathrm{CO}_{3}$ (1.5 equiv.), DMA $(3 \mathrm{~mL}), 90{ }^{\circ} \mathrm{C}, 3-5 \mathrm{~h}$.

d) Isolated yields after purification

We have further extended the scope of our procedure to synthesize different higher analogues of phenanthridines. With the aforesaid optimal set of reaction conditions we have synthesized benzo $[k]$ phenanthridines 3.41a-c and benzo[i]phenanthridine $\mathbf{3 . 4 2}$ from the corresponding bromonaphthaldehyde in good yields (Table 3.3). Here also different functionalities have been well tolerated. 
Table 3.3: Synthesis of phenanthrine analogs ${ }^{\mathrm{e}}$

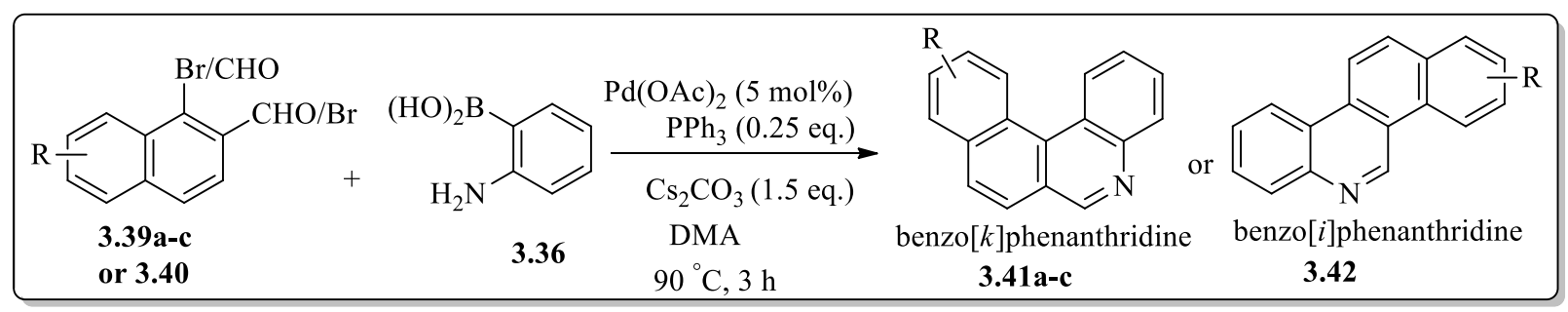

Entry

a) Reaction Conditions and Reagents: $1 \mathrm{mmol}$ of substrate 3.39a-c or 3.40, $1.2 \mathrm{mmol}$ of aminobenzeneboronic acid 3.36, $\mathrm{Pd}(\mathrm{OAc})_{2}$ ( $\left.5 \mathrm{~mol} \%\right), \mathrm{PPh}_{3}$ (0.25 equiv.), $\mathrm{Cs}_{2} \mathrm{CO}_{3}$ (1.5 equiv.), DMA (3mL), $90{ }^{\circ} \mathrm{C}, 3-5 \mathrm{~h}$.

b) Isolated yields. 
The cyclization reaction was believed to follow the sequential steps of Suzuki coupling followed by condensation. The Suzuki coupling occurs first between the coupling partners to produce the intermediate $\mathbf{I}$ which then undergoes intramolecular cyclization to afford the phenanthridine II. In contrast, if the condensation is to be occurred first it would result the more stable trans-imine III from which intramolecular coupling is quite impossible as the two functional groups are far apart (Fig 3.3). Evidence in support of our proposal comes from that fact no imine was isolated during the reaction course.

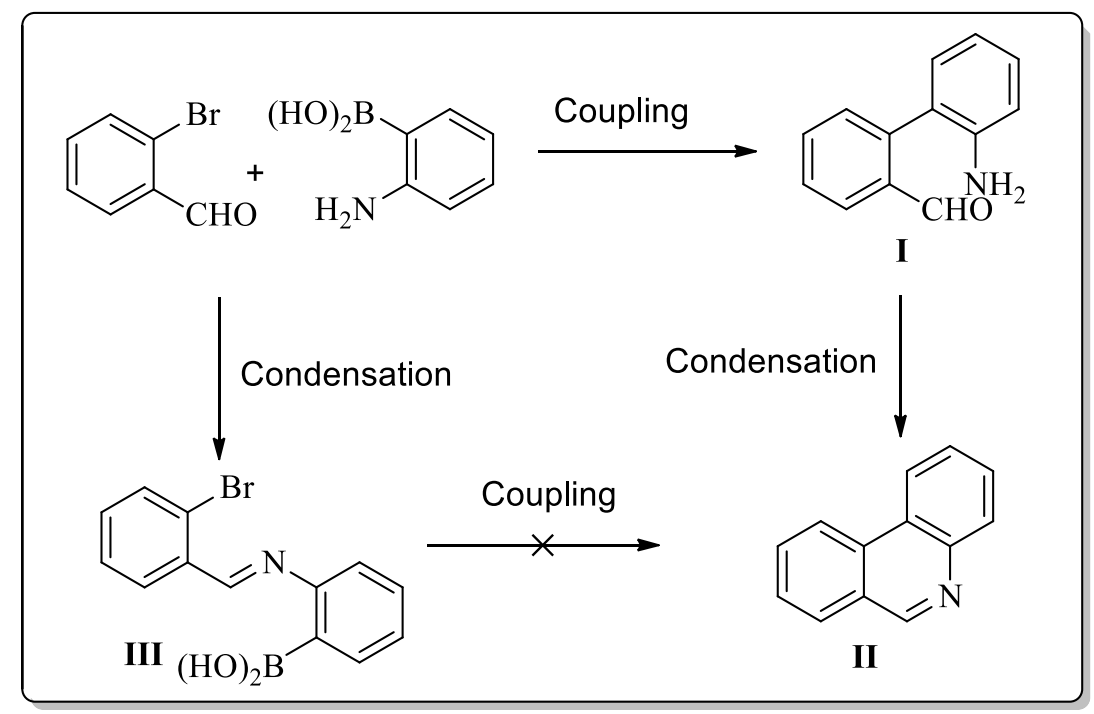

Fig 3.3: Plausible course of the reaction

\subsection{Experiments and Results Section}

\subsubsection{General procedure for the preparation of aromatic naphthaldehyhe (3.45):}

A mixture of $1 \mathrm{mmol}$ of ortho-bromovinylaldehyde and $3 \mathrm{mmol}$ of DDQ were taken in dry benzene in a $25 \mathrm{~mL}$ two necked round bottomed flask and refluxed for overnight. Completion of the reaction was confirmed TCL. After completion of the reaction the mixture was cool to room temperature and benzene was evaporated under reduced pressure. The crude product was purified the usual column chromatography using silica gel and mixture of petroleum ether and ethyl acetate as eluents.

\subsubsection{General procedure of Suzuki coupling for synthesis of phenanthridine (3.38):}

Ortho-bromobenzaldehyde (50 $\mathrm{mg}, 0.273 \mathrm{mmol}$ ), ortho-aminobenzeneboronic acid (53.5 mg, 1.2 equiv.), $\mathrm{Pd}(\mathrm{OAc})_{2}$ (5 mol\%), $\mathrm{PPh}_{3}$ (0.25 equiv.), $\mathrm{Cs}_{2} \mathrm{CO}_{3}$ (133.5 mg, 1.5 equiv.) were taken in a two-necked round bottom flask in argon atmosphere. $3 \mathrm{~mL}$ of dry DMA was 
added to the reaction mixture and degassed with nitrogen and heated at $90{ }^{\circ} \mathrm{C}$ temperature for $3 \mathrm{~h}$. Completion of the reaction was monitored by TLC. The reaction mixture was cooled to rt and diluted with water. It was then extracted with ethyl acetate $(50 \mathrm{~mL} \times 3)$. Combined organic layer was washed with brine and dried over anhydrous $\mathrm{Na}_{2} \mathrm{SO}_{4}$. The solvent was evaporated under reduced pressure and crude product was purified by column chromatography using Silica gel and petroleum ether: ethyl acetate (5:1) as eluent.

\section{Spectral data of the representative Compounds:}

\section{Phenanthridine (3.38a):}

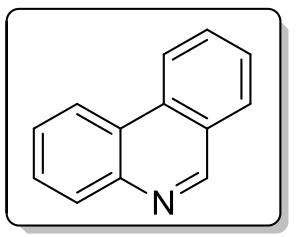

Yellow solid, mp: 102-104 ${ }^{0} \mathrm{C}$ (lit. ${ }^{1}$ 104-106 ${ }^{\circ} \mathrm{C}$ ); Yields : $90 \%$; ${ }^{1} \mathrm{H}$ NMR $\left(\mathrm{CDCl}_{3}, 200 \mathrm{MHz}\right): 9.18(1 \mathrm{H}, \mathrm{s}), 8.41(2 \mathrm{H}, \mathrm{d}, J=8.0 \mathrm{~Hz}), 8.17(1 \mathrm{H}, \mathrm{dd}$, $\left.J_{l}=1.2 \mathrm{~Hz}, J_{2}=8.0 \mathrm{~Hz}\right), 7.87(1 \mathrm{H}, \mathrm{t}, J=7.0 \mathrm{~Hz}), 7.52-7.75(4 \mathrm{H}, \mathrm{m}) ;{ }^{13} \mathrm{C}$

NMR ( $\left.\mathrm{CDCl}_{3}, 50 \mathrm{MHz}\right): 153.4,144.1,132.4,131.0,129.9,128.7$ (2C), 127.4, 127.1, 126.2, 124.0, 122.2, 121.7; Anal.Calcd for $\mathrm{C}_{13} \mathrm{H}_{9} \mathrm{~N}: \mathrm{C}: 87.12 ; \mathrm{H}: 5.06 ; \mathrm{N}: 7.82$ $\%$; Found: C: 87.00; H: 4.95; N: $7.72 \%$.

\section{2,3-dimethoxyphenanthridine (3.38c):}

Brown solid; mp: $127-129{ }^{\circ} \mathrm{C}$ Yield: $85 \% ;{ }^{1} \mathrm{H} \mathrm{NMR}\left(\mathrm{CDCl}_{3}, 400\right.$

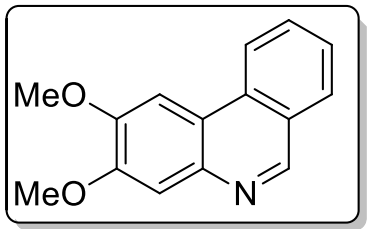

MHz): $9.17(1 \mathrm{H}, \mathrm{s}), 8.45(1 \mathrm{H}, \mathrm{d}, J=7.6 \mathrm{~Hz}), 8.16(1 \mathrm{H}, \mathrm{d}, J=8.0$ Hz), 7.89 (1H, s), 7.63-7.71 (2H, m), $7.37(1 \mathrm{H}, \mathrm{s}), 4.15(3 \mathrm{H}, \mathrm{s}), 4.10$ $(3 \mathrm{H}, \mathrm{s}) ;{ }^{13} \mathrm{C} \mathrm{NMR}\left(\mathrm{CDCl}_{3}, 100 \mathrm{MHz}\right): 153.2,152.0,150.2,139.5$, $130.3,130.0128 .5,128.0,126.8,121.9,114.3,108.1,102.1,56.4$,

56.3; Anal.Calcd for $\mathrm{C}_{15} \mathrm{H}_{13} \mathrm{NO}_{2}$ : C: 75.30; H: 5.48; N: $5.85 \%$; Found : C: 75.25; H: 5.36; $\mathrm{N}: 5.72 \%$.

\section{1,2,3-trimethoxyphenanthridine (3.38d):}

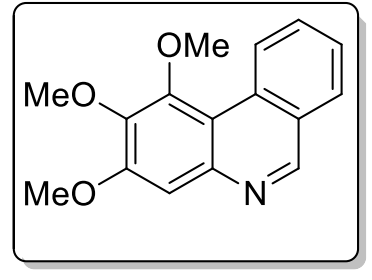

Brown Sticky masss; Yield: $78 \%$; ${ }^{1} \mathrm{H}$ NMR $\left(\mathrm{CDCl}_{3}, 200 \mathrm{MHz}\right): 9.34$ $\left(1 \mathrm{H}, \mathrm{dd}, J_{1}=2.4 \mathrm{~Hz}, J_{2}=7.0 \mathrm{~Hz}\right), 9.14(1 \mathrm{H}, \mathrm{s}), 8.18(1 \mathrm{H}, \mathrm{t}, J=7.0$ $\mathrm{Hz}), 7.27-7.71(2 \mathrm{H}, \mathrm{m}), 7.27(1 \mathrm{H}, \mathrm{s}), 4.10(9 \mathrm{H}, \mathrm{s}) ;{ }^{13} \mathrm{C} \mathrm{NMR}\left(\mathrm{CDCl}_{3}\right.$, $50 \mathrm{MHz}$ ): 153.6, 152.6, 151.6, 146.6, 144.2, 130.0, 127.9, 127.4, 126.4, 124.3, 123.8, 121.8, 105.4, 61.5, 60.6, 56.3; Anal.Calcd for $\mathrm{C}_{16} \mathrm{H}_{15} \mathrm{NO}_{3}: \mathrm{C}: 79.09 ; \mathrm{H}: 5.23 ; \mathrm{N}: 6.50 \%$; Found : C: 79.0; H: 5.15; N: $6.43 \%$; HRMS calcd for $\mathrm{C}_{16} \mathrm{H}_{16} \mathrm{NO}_{3}{ }^{+}\left[\mathrm{M}+\mathrm{H}^{+}\right]: 270.1125$; Found : 270.1125 . 


\section{Conclusion}

In conclusion a simple and efficient method for the synthesis of different substituted phenanthridine and it higher analogues benzo $[k]$ and benzo[i] derivatives have been developed. Our synthetic strategy is a general one with tolerability to a variety of substituent and gave highly substituted phenanthridines in quite good yields from very cheap starting materials under mild reaction conditions. We anticipate that our methodology could be applicable to synthesize phenanthridine natural products of important medicinal value $e^{5,8,10,14-}$ 40.

\section{References}

1. Suzuki, A., Organoboron compounds in new synthetic reactions. Pure and Applied Chemistry 1985, 57 (12), 1749-1758.

$2 . \quad$ Ray, D.; Ray, J. K., Novel Synthetic Approach Toward ( \pm )- $\beta$-Cuparenone via Palladium-Catalyzed Tandem Heck Cyclization of 1-Bromo-5-methyl-1-aryl-hexa-1, 5-dien3-ol Derivatives. Organic letters 2007, 9 (2), 191-194.

3. Samanta, S.; Mohapatra, H.; Jana, R.; Ray, J. K., Pd (0) catalyzed intramolecular Heck reaction: a versatile route for the synthesis of 2-aryl substituted 5-, 6-, and 7-membered O-containing heterocycles. Tetrahedron Letters 2008, 49 (50), 7153-7156.

4. Nandi, S.; Singha, R.; Samanta, S.; Ray, J. K., Synthesis of pentalongin and C (1)and C (3)-substituted pentalongin using intramolecular Heck reaction. Tetrahedron Letters 2012, 53 (21), 2659-2661.

5. $\quad$ Ray, D.; Nasima, Y.; Sajal, M. K.; Ray, P.; Urinda, S.; Anoop, A.; Ray, J. K., Palladium-Catalyzed Intramolecular Oxidative Heck Cyclization and Its Application toward a Synthesis of $( \pm)$ - $\beta$-Cuparenone Derivatives Supported by Computational Studies. Synthesis 2013, 45 (09), 1261-1269.

6. Dey, D.; Bhattacharya, T.; Majumdar, B.; Mandani, S.; Sharma, B.; Sarma, T. K., Carbon dot reduced palladium nanoparticles as active catalysts for carbon-carbon bond formation. Dalton Transactions 2013, 42 (38), 13821-13825.

7. Yamamoto, Y., Synthesis of heterocycles via transition-metal-catalyzed hydroarylation of alkynes. Chemical Society Reviews 2014, 43 (5), 1575-1600.

8. $\quad$ Ray, J. K.; Paul, S.; Ray, P.; Singha, R.; Rao, D. Y.; Nandi, S.; Anoop, A., Pdcatalyzed intramolecular sequential Heck cyclization and oxidation reactions: a facile pathway for the synthesis of substituted cycloheptenone evaluated using computational studies. New Journal of Chemistry 2017, 41 (1), 278-284.

9. Ghosh, M.; Ray, J. K., Ten years advancement in the synthetic applications of 2bromo-cyclohexenecarbaldehydes and 2-bromobenzaldehydes and derived substrates under palladium-catalyzed cross-coupling conditions. Tetrahedron 2017, 73 (27), 3731-3799.

10. Ray, J. K.; Singha, R.; Ray, D.; Ray, P.; Rao, D. Y.; Anoop, A., Palladiumcatalyzed expedient Heck annulations in 1-bromo-1,5-dien-3-ols: Exceptional formation of fused bicycles. Tetrahedron Letters 2019, 60 (13), 931-935.

11. Milstein, D.; Stille, J. K., Mechanism of reductive elimination. Reaction of alkylpalladium(II) complexes with tetraorganotin, organolithium, and Grignard reagents. 
Evidence for palladium(IV) intermediacy. Journal of the American Chemical Society 1979, 101 (17), 4981-4991.

12. Nakao, Y.; Hiyama, T., Silicon-based cross-coupling reaction: an environmentally benign version. Chemical Society Reviews 2011, 40 (10), 4893-4901.

13. Negishi, E.-i., Magical Power of Transition Metals: Past, Present, and Future (Nobel Lecture). Angewandte Chemie International Edition 2011, 50 (30), 6738-6764.

14. Wang, C.-Y.; Ray, P.; Gong, Q.; Zhao, Y.; Li, J.; Lueking, A. D., Influence of gas packing and orientation on FTIR activity for $\mathrm{CO}$ chemisorption to the $\mathrm{Cu}$ paddlewheel. Physical Chemistry Chemical Physics 2015, 17 (40), 26766-26776.

15. Chaudhuri, S.; Maity, S.; Roy, M.; Ray, P.; Ray, J. K., A Vinyl Radical Cyclization Route to Hydroxycyclohexene Fused Carbocycles. Asian Journal of Chemistry 2016, 28 (1).

16. Ray, P., Interactions of nitrogen and hydrogen with various $1 \mathrm{D}$ and 3D carbon materials probed via in-situ vibrational spectroscopy. $P h$. D. Thesis 2016.

17. Ray, P.; Gray, J. L.; Badding, J. V.; Lueking, A. D., High-Pressure Reactivity of Triptycene Probed by Raman Spectroscopy. The Journal of Physical Chemistry B 2016, 120 (42), 11035-11042.

18. Ray, P.; Xu, E.; Crespi, V. H.; Badding, J. V.; Lueking, A. D., In situ vibrational spectroscopy of adsorbed nitrogen in porous carbon materials. Physical Chemistry Chemical Physics 2018, 20 (22), 15411-15418.

19. Ray, P.; Gidley, D.; Badding, J. V.; Lueking, A. D., UV and chemical modifications of polymer of Intrinsic Microporosity 1 to develop vibrational spectroscopic probes of surface chemistry and porosity. Microporous and Mesoporous Materials 2019, 277, 29-35.

20. Ray, P. Calixarenes and Nanoparticles: Synthesis, Properties and Applications. Paris 11, 2013.

21. Singha, R.; Roy, S.; Nandi, S.; Ray, P.; Ray, J. K., Palladium-catalyzed one-pot Suzuki-Miyaura cross coupling followed by oxidative lactonization: a novel and efficient route for the one-pot synthesis of benzo[c]chromene-6-ones. Tetrahedron Letters 2013, 54 (7), 657-660.

22. André, E.; Boutonnet, B.; Charles, P.; Martini, C.; Aguiar-Hualde, J. M.; Latil, S.; Guérineau, V.; Hammad, K.; Ray, P.; Guillot, R.; Huc, V., A New, Simple and Versatile Strategy for the Synthesis of Short Segments of Zigzag-Type Carbon Nanotubes. Chemistry 2016, 22 (9), 3105-14.

23. Brahma, S.; Ray, P.; Singha, R.; Ray, J. K., Visible Colourimetric and Ratiometric Fluorescent Chemosensors for Cu (II) and Ni (II) Ions. Asian Journal of Chemistry 2016, 28 (5), 1035.

24. Ray, P.; Clément, M.; Martini, C.; Abdellah, I.; Beaunier, P.; Rodriguez-Lopez, J.L.; Huc, V.; Remita, H.; Lampre, I., Stabilisation of small mono- and bimetallic gold-silver nanoparticles using calix[8]arene derivatives. New Journal of Chemistry 2018, 42 (17), 14128-14137.

25. Ghosh, A.; Sarkar, S.; Ghosh, S.; Ray, P.; Quadir, M.; Banerjee, S. K.; Banerjee, S., Abstract 1234: Zoledronic acid-induced suppression of invasive phenotypes of pancreatic cancer cells is mediated through downregulation of CYR61/CCN1. Cancer Research 2019, 79 (13 Supplement), 1234.

26. Ray, P.; Ferraro, M.; Haag, R.; Quadir, M., Dendritic Polyglycerol-Derived NanoArchitectures as Delivery Platforms of Gemcitabine for Pancreatic Cancer. Macromol Biosci 2019, 19 (7), e1900073.

27. Ray, P.; Alhalhooly, L.; Ghosh, A.; Choi, Y.; Banerjee, S.; Mallik, S.; Banerjee, S.; Quadir, M., Size-Transformable, Multifunctional Nanoparticles from Hyperbranched Polymers for Environment-Specific Therapeutic Delivery. ACS Biomaterials Science \& Engineering 2019, 5 (3), 1354-1365. 
28. Ray, P.; Confeld, M.; Borowicz, P.; Wang, T.; Mallik, S.; Quadir, M., PEG-b-poly (carbonate)-derived nanocarrier platform with $\mathrm{pH}$-responsive properties for pancreatic cancer combination therapy. Colloids and Surfaces B: Biointerfaces 2019, 174, 126-135.

29. Ray, P.; Nair, G.; Ghosh, A.; Banerjee, S.; Golovko, M. Y.; Banerjee, S. K.; Reindl, K. M.; Mallik, S.; Quadir, M., Microenvironment-sensing, nanocarrier-mediated delivery of combination chemotherapy for pancreatic cancer. Journal of Cell Communication and Signaling 2019.

30. Abdullah, C. S.; Ray, P.; Alam, S.; Kale, N.; Aishwarya, R.; Morshed, M.; Dutta, D.; Hudziak, C.; Banerjee, S. K.; Mallik, S.; Banerjee, S.; Bhuiyan, M. S.; Quadir, M., Chemical Architecture of Block Copolymers Differentially Abrogate Cardiotoxicity and Maintain the Anticancer Efficacy of Doxorubicin. Molecular Pharmaceutics 2020, 17 (12), 4676-4690.

31. Clément, M.; Abdellah, I.; Ray, P.; Martini, C.; Coppel, Y.; Remita, H.; Lampre, I.; Huc, V., Synthesis and NMR study of trimethylphosphine gold(i)-appended calix[8]arenes as precursors of gold nanoparticles. Inorganic Chemistry Frontiers 2020.

32. Confeld, M. I.; Mamnoon, B.; Feng, L.; Jensen-Smith, H.; Ray, P.; Froberg, J.; Kim, J.; Hollingsworth, M. A.; Quadir, M.; Choi, Y.; Mallik, S., Targeting the tumor core: hypoxia-responsive nanoparticles for delivery of chemotherapy to pancreatic tumors. Molecular Pharmaceutics 2020.

33. Babak, K.; Torabi, M.; Foad, K.; Priyanka, R., Novel $\beta$-Cyclodextrin Functionalized Core-Shell Fe3O4 Magnetic Nanoparticles for the Removal of Toxic Metals from Water. 2021.

34. Brahma, S.; Ray, P.; Ray, J. K., Synthesis of azirines containing aldehyde functionality and their utilization as synthetic tools for five membered oxazoles and isoxazoles (vol 45, pg 311, 2008). JOURNAL OF HETEROCYCLIC CHEMISTRY 2021, 58 (6), 1388-1388.

35. Das, A.; Haque, I.; Ray, P.; Ghosh, A.; Dutta, D.; Quadir, M.; De, A.; Gunewardena, S.; Chatterjee, I.; Banerjee, S.; Weir, S.; Banerjee, S. K., CCN5 activation by free or encapsulated EGCG is required to render triple-negative breast cancer cell viability and tumor progression. Pharmacol Res Perspect 2021, 9 (2), e00753.

36. Ray, P., Polymer based drug delivery systems-benchtop to bedside transition. Journal of Drugs Addiction \& Therapeutics. SRC/JDAT-114 2021, 3.

37. Ray, P., Curing Cancer with Nanotherapy Continues to be an Elusive Goal. Journal of Immunological Sciences 2021, 5 (2).

38. Ray, P.; Dutta, D.; Haque, I.; Nair, G.; Mohammed, J.; Parmer, M.; Kale, N.; Orr, M.; Jain, P.; Banerjee, S.; Reindl, K. M.; Mallik, S.; Kambhampati, S.; Banerjee, S. K.; Quadir, M., pH-Sensitive Nanodrug Carriers for Codelivery of ERK Inhibitor and Gemcitabine Enhance the Inhibition of Tumor Growth in Pancreatic Cancer. Molecular Pharmaceutics 2021, 18 (1), 87-100.

39. Ray, P.; Haideri, N.; Haque, I.; Mohammed, O.; Chakraborty, S.; Banerjee, S.; Quadir, M.; Brinker, A. E.; Banerjee, S. K., The Impact of Nanoparticles on the Immune System: A Gray Zone of Nanomedicine. Journal of Immunological Sciences 2021, 5 (1).

40. Ray, P.; Kale, N.; Quadir, M., New side chain design for $\mathrm{pH}$-responsive block copolymers for drug delivery. Colloids and Surfaces B: Biointerfaces 2021, 200, 111563. 